\title{
Russia's great power imaginary and pursuit of digital multipolarity
}

\author{
Stanislav Budnitsky \\ Annenberg School for Communication, University of Pennsylvania, Philadelphia, United States of \\ America
}

Published on 26 Aug 2020 | DOI: 10.14763/2020.3.1492

\begin{abstract}
Over the past two decades, Russia has championed the primacy of national governments in managing the global internet. Scholars attribute Russia's global internet governance philosophy and practices predominantly to its increasingly authoritarian and illiberal regime under President Vladimir Putin. This article, by contrast, explores how Russian ruling elites' view of Russia as an immutable great power has directed the subsequent Russian governments' pursuit of a state-based multipolar digital order. To illuminate cultural continuities in Russia's approach to global communication governance in the post-Soviet period, I examine its state-centric policymaking initiatives at the International Telecommunication Union and the United Nations in the 1990s.
\end{abstract}

Keywords: Global internet governance, International Telecommunication Union, International information security, National identity, Russia

\section{Article information}

Received: 05 Feb 2020 Reviewed: 29 Mar 2020 Published: 26 Aug 2020

Licence: Creative Commons Attribution 3.0 Germany

Competing interests: The author has declared that no competing interests exist that have influenced the text.

URL:

http://policyreview.info/articles/analysis/russias-great-power-imaginary-and-pursuit-digital-multipolar ity

Citation: Budnitsky, S. (2020). Russia's great power imaginary and pursuit of digital multipolarity. Internet Policy Review, 9(3). https://doi.org/10.14763/2020.3.1492

\section{INTRODUCTION}

In the twenty-first century, Russia has spearheaded an international movement for the primacy of national governments in managing the internet. The geopolitical debate surrounding internet governance pits supporters of administering the global internet's critical resources and standards via state-based multilateral institutions against those favouring the present distribution of governance functions between state and non-state actors (DeNardis, 2014; Mueller, 2010, 2017; Radu, 2019). This article offers a cultural reading of Russia's approach to 
global internet governance. It argues that Russian ruling elites' imaginary of Russia as a historic great power deserving of full participation in global governance has directed the state's promotion of internet multilateralism and its challenge to the perceived US digital hegemony.

Social imaginaries, in philosopher Charles Taylor's formulation, are the "common repertory" of people's conceptions of their surroundings, normative expectations of how things in the world should proceed, and understandings of what actions are at their disposal - all of which "enables us to carry out the collective practices that make up our social life" (Taylor, 2003, pp. 23-26). The laws, standards, and norms governing technologies reflect social imaginaries: both through people's concerted efforts to embed their views and expectations into technological design and operation and through taken-for-granted assumptions that guide individuals' and collectives' relations with technology (Jasanoff \& Kim, 2015; Mansell, 2012). In particular, national policymaking elites make sense of and act upon the internet against their ideas about the respective nation's identity and place in the world (Dumitrica, 2015).

The proposed focus on national imaginaries of Russian policymaking elites serves as an alternative analytical lens to a broad scholarly consensus that regards Russia's global internet agenda as an expression of President Vladimir Putin's political regime. Some scholars situate Russia's approach to global digital technologies within the context of the renewed ideological struggle between liberal democracies and illiberal governments (e.g., Maréchal, 2017; Polyakova \& Meserole, 2019; Rosenbach \& Mansted, 2019; Soldatov \& Borogan, 2015, Ch. 11). For example, Robert Morgus, then New America Foundation's cybersecurity analyst, attributed Russia's “digital authoritarianism" to Putin's "paranoias" about the dictate of US values and interests over the global internet (Morgus, 2018). Another scholarly strand emphasises the Kremlin's concerns with state security and social control as primary motivations for its internet governance philosophy (e.g., Claessen, 2020; Deibert \& Crete-Nishihata, 2012; Franke \& Pallin, 2012, pp. 62-64; Kennedy, 2013; Nocetti, 2015; Pigman, 2019; Stadnik, 2019). According to American University's internet governance scholar Laura DeNardis, for instance, authoritarians like Russia and China support internet multilateralism "under the mantel of cyber sovereignty" to establish cultural and political control over their citizenry, such as the Russian state's recent online crackdown on the country's sexual minorities "under the guise of preserving social order" (DeNardis, 2020, pp. 180-183).

Yet others consider Russia's internet internationalisation agenda as part of the politicaleconomic rise of non-Western powers and their ensuing challenge to the Western dominance over global political economy of telecommunication (e.g., Ebert \& Maurer, 2013; Freedman \& Wilkinson, 2013; Polatin-Reuben \& Wright, 2014; Rebello, 2017; Zhao, 2015). Carleton University's telecommunication scholar Dwayne Winseck posits that, in addition to making inroads into the geopolitical economy of internet infrastructure, Russia and China "are also trying to add international legal norms steeped in nineteenth-century views of state security that would further entrench the semiautonomous, national web 3.0 model in a multilateral model of internet governance" (2017, p. 260). Lastly, Kieron O'Hara and Wendy Hall, computer scientists and social thinkers at the University of Southampton, place what they term "Moscow's Spoiler Model” of global internet governance outside of conventional politics altogether (O'Hara \& Hall, 2018, pp. 11-13). According to the authors, Russian leadership's ideological mix of nationalism, victimhood, cynicism, and conspiratorial thinking drives the Kremlin's strategy of "free riding on the efforts of others to produce a valuable information space" with the sole aim of sabotaging the liberal West in cyberspace and beyond.

In contrast with the prevailing scholarly focus on the role of Putin's persona and regime in 
Russia's internet governance, this article aims to disentangle the longer-term cultural factors underlying Russia's global internet agenda from the current regime's political ideologies and practices. After the end of the Cold War, the Russian leadership viewed Russia as an immutable great power with continued responsibility for global affairs. Consequently, Russia has opposed the emergent US-led unipolarity and instead promoted the ideal of a multipolar world order governed collectively through intergovernmental multilateral institutions. In the domain of internet governance, Russia similarly has advanced the primacy of state sovereignty over respective national internet segments, diversification of internet governance mechanisms and markets purportedly monopolised by the US public and private actors, and the leading role of the United Nations and its specialised agency, the International Telecommunication Union (ITU), in managing the global internet. Accordingly, I conceptualise Russia's quest to reconfigure the global digital order based on the principles and language of multipolarity as digital multipolarity.

In order to analytically detach the cultural logics underlying Russia's pursuit of digital multipolarity from its commonly acknowledged pivot toward greater political authoritarianism and illiberalism under Putin's rule (Gel'man, 2015; Kolstø \& Blakkisrud, 2016), I illuminate how the principles of multipolarity directed Russian digital governance initiatives in the $1990 \mathrm{~s}-\mathrm{a}$ decade preceding Putin's rise to power. The first data set pertains to Russia's advocacy of statebased global telecommunication governance at the International Telecommunication Union Plenipotentiary Conferences held in 1992, 1994, and 1998. I located Russian delegations' contributions to these meetings within the materials available at the ITU online archive (International Telecommunication Union, n.d.). My analysis incorporates Russian representatives' addresses to the plenary, proposals for the work of the conference, draft resolutions, and meeting minutes. The second set of data concerns the resolution Russia first proposed to the UN General Assembly (UNGA) in 1998 entitled Developments in the field of information and telecommunications in the context of international security. The resolution is widely considered to have inaugurated information security discussions at the United Nations (e.g., Chernenko, 2018, p. 43; Henriksen, 2019, p. 2; Maurer 2011, p. 16; Radu, 2019, p. 102). Through the searchable UN Digital Library, I located documents from 1998-99 that directly related to the resolution, such as Russian diplomats' addresses at the UNGA that introduced the resolution and Russia's elaboration of its international information security vision submitted to the UN Secretary-General.

I conducted discursive analysis of Russian policymaking initiatives at the ITU and the UN. Following British cultural sociologist Rosalind Gill (2018), I understand discourse as textual construction of a particular version of the world set against competing visions. The analytical goal, as Gill explains, is to understand and illuminate the ideological premises that run through a particular discourse. The methodological task, then, consists of identifying what Gill calls "interpretive repertoires"-recurrent themes, ideas, or tropes-within the delineated corpus of texts and situating them within larger social contexts and cultural shifts.

By juxtaposing repertoires excavated in Russian discourse of multipolarity and of digital governance, I show how the Russian state's conceptions and language of the multipolar world enable its vision of global communications. This relationship between Russia's national and technological imaginaries is best understood as "constitutive causality" (Schwartz-Shea \& Yanow, 2012, p. 52). Rather than establishing a mechanistic causality between cultural context and political action, this analytical approach explores how "humans conceive of their worlds, the language they use to describe them, and other elements constituting that social world, which make possible or impossible the interactions they pursue" (Ibid.). My argument, then, is not that 
Russia's normative conceptions of its greatness and of world multipolarity make its state-centric internet governance agenda inevitable, but that they make it conceptually imaginable and therefore politically possible.

In addition to enriching literature on Russia's global communication philosophy and practice, this paper contributes a novel approach to internet governance studies that takes national narratives about the self and its place in the world seriously. Internet governance scholarship, to date, has privileged the lenses of law, political economy, international relations, and science and technology studies (e.g., Brousseau et al., 2012; Bygrave \& Bing, 2009; Choucri \& Clark, 2019; Kohl, 2017; Musiani et al., 2016). Socio-cultural approaches examining internet governance actors' visions and narratives constitute a minority (e.g., Chenou, 2014; Pohle et al., 2016; Price, 2017), particularly those focusing on national identities (e.g., Kiggins, 2012; Schulte, 2013). Using the Russian case, I show how centring national identity narratives in the analysis of states' internet governance agendas can add further nuance to their understanding.

This article proceeds in three parts. First, I contextualise Russia's multipolarity framework within the socio-political circumstances of its emergence in the $1990 \mathrm{os}$ and deconstruct its normative claims. Next, I illuminate how the multipolarity framework underlays the logics and language of Russia's policymaking initiatives at the ITU and the UN in the 1990s. Lastly, I show how Russia's global internet governance agenda arising in the 2000-2010s incorporated multipolarity principles and rhetoric of the preceding decade. By tracing Russia's great power imaginary and pursuit of the multipolar world order to its most liberal years of the early 1990s, I challenge the prevailing analytical coupling of Russia's internet governance agenda with the Russian state's authoritarian political tendencies under Putin's rule.

\section{GREAT POWER IMAGINARY AND MULTIPOLARITY}

A country's foreign policy is normally a reflection of its governing elites' prevailing consensusbased understanding of the nation's identity and ensuing geopolitical priorities (Ringmar, 1996; Weldes, 1999). Since Peter the Great's (1682-1725) campaign to turn the Russian tsardom into a modern European power, the country's ruling elites have imagined Russia as a great power responsible for world affairs and strove to be recognised as such by the West (Neumann, 2008a, 2008b; Prizel, 1998; Ringmar, 2002; Tolz, 2001). Despite Russia's significant geopolitical weakening in the aftermath of the Soviet Union's breakup, the elite imaginary of Russia as an immutable great power persisted into the post-Soviet era (Clunan, 2014; Lo, 2002).

Andrei Tsygankov, a leading US-based scholar of Russian foreign policy, posits that since the eighteenth century, representatives of three schools of foreign policy thought-Westernisers, Statists, and Civilisationists-have competed to guide Russia's engagement with the world in accordance with their respective visions of the country's national identity (Tsygankov, 2019; see also Thorun, 2009, Ch. 3). In the post-Soviet years, Westernisers steered Russian foreign policymaking during Boris Yeltsin's first presidential term (1990-96) under Foreign Minister Andrey Kozyrev (1990-96) and sought integration with the Euro-Atlantic world based on shared liberal values, particularly in 1991-1993. The Statist period that followed began with Yevgeny Primakov's terms as Foreign Minister (1996-98) and Prime Minister (1998-99) during Yeltsin's second presidential term (1996-99). Statists range from liberal to conservative wings and view the primary goal of the state as maintaining domestic economic and political order and ensuring security from external threats. Statists are not inherently anti-Western but seek recognition of Russia's sovereignty as a prerequisite to pragmatic cooperation. Lastly, Civilisationists emphasise Russia's cultural distinctiveness and most categorically challenge Western liberalism. Foreign policy under Vladimir Putin's rule gradually moved from the more liberal to more 
conservative flanks of Statism while increasingly incorporating Civilisational motifs, particularly following the regime's conservative turn of 2012-14.

While Russian intellectual and political elites disagree about the precise sources of Russia's greatness, they uniformly believe that the country's independence in domestic governance and unimpeded participation in global governance are indispensable conditions of its great power status (Lo, 2002, pp. 57-61; Trenin, 2011, pp. 411-417). Russia's desire for regaining the strategic independence partially lost with the demise of the Soviet Union gave rise to multipolarity as its central foreign policy framework (Ambrosio, 2005; Chebankova, 2017; Lo, 2002, pp. 86-96; Miskimmon \& O'Loughlin, 2017; Silvius, 2016). Russia envisions global governance conducted by multiple powers, or poles, in place of the US unipolar dominance.

The foundational repertoires of Russia's multipolarity narrative have remained virtually unchanged since its emergence in the early 1990s. In Russia's conceptualisation, the basis of the multipolar world order is the inviolability of state sovereignty. Sovereignty, in turn, manifests itself in states' ability to conduct independent domestic and foreign policy free from outside interference into their internal affairs. Meanwhile, the repertoire of diversity conveys the notion that the world is comprised of sovereign nations with equally valuable cultural, social, and political systems. Russia posits a multipolar world as more democratic, just, and equal, because multipolarity purportedly respects sovereign peoples' rights to live in accordance with their respective political ideologies and cultural beliefs.

The main threat to domestic sovereignty and global diversity, according to Russia's multipolarity narrative, is the unipolar hegemony or monopoly of the United States (often referred to with euphemisms of "one country" and "sole power"). The hegemon, whose behaviour is regularly described in anthropomorphic terms of arrogance, cynicism, and egoism, imposes its will on others, disregarding national interests and identities. The inherent tension between the hegemon's desire for domination and the diversity of countries' foreign policy interests undermines global peace and stability, particularly when the hegemon resorts to coercion of military force and economic sanctions. The only instruments of global governance capable of satisfactorily representing diverse national interests and containing destructive impulses of the hegemon are international law and multilateral diplomacy, foremost the United Nations and its Security Council.

From the first months of Russia's post-Soviet independence, still at the height of its EuroAtlantic orientation, Russian leadership was already promoting key multipolarity claims. During the foreign policy dominance of Westernisers in the early 1990s, the Kremlin's multipolarity narrative presented Russia as a liberal great power that sought to become a democratic market economy aligned with the Euro-Atlantic world (Tsygankov, 2019, Ch. 3). For example, at the UNGA in September 1992, Foreign Minister Kozyrev described Russia as "a normal rather than an aggressive great Power" that "rejected communism" and "imperialistic ambitions", and argued that the "post-confrontational and post-communist world is not a pax Sovietica, a pax Americana, a pax Islamica or a pax Christiana, nor is it a monopolistic system of any kind, but rather the multipolar unity in diversity that the United Nations has symbolized from the very outset" (Kozyrev, 1992, pp. 57-59). Although the Russian foreign policy establishment did not yet self-consciously think of such claims in terms of a coherent multipolarity doctrine, it incorporated propositions promoting multilateral UN-based global governance in opposition to the US dominance into Russia's inaugural Foreign Policy Concept adopted in spring 1993 (Russian Federation, 2005 [1993]).

Russia's multipolarity narrative under Kozyrev, moreover, often was employed in support of 
closer relations with the liberal West. In 1994, for example, Kozyrev argued for a more meaningful partnership with the USA in Russia's Izvestia newspaper and in the US magazine Foreign Affairs (Kozyrev, 1994a, 1994b). In Izvestia, Kozyrev claimed greatness to be Russia's transcendental trait, suggesting that Russia historically was "doomed to be a great power" and always "will remain a superpower" (Kozyrev, 1994b). While proposing that Russian and American great powers "share common values" and have "mutually complementary" national interests, Kozyrev nevertheless harshly criticised what he called the US administration's "almost maniacal desire to see only one leading power in today's world" and to "obsessively declare American leadership". Articulating an alternative to the unipolar geopolitical arrangement, Kozyrev argued that Russia ought to govern the multipolar world as "an equal partner, not a junior one" of the United States. Russia, in other words, was not opposed to the US liberal values as such but resisted the United States' perceived abuse of its economic and military superiority to the detriment of other great powers in global governance.

In early 1996, Yevgeny Primakov, the then-head of the Russian Foreign Intelligence Service, replaced Kozyrev as foreign minister. Primakov's appointment signalled elites' disenchantment with the ideal of Western integration and turn toward greater statism in foreign policy. Under Primakov, Russia strove to counterbalance the US by diversifying its foreign policy orientations after Kozyrev's overwhelming focus on the West (Ambrosio, 2005, Ch. 4-5; Tsygankov, 2019, Ch. 4). Russia's diversification efforts ranged from Primakov's first tours of Latin American countries by a high-level Russian official in the post-Soviet period to the establishment of the Shanghai Five, a precursor to the Shanghai Cooperation Organisation (SCO). China in particular became Russia's close ally in this period (Ambrosio, 2005, pp. 78-89).

Primakov was instrumental in reframing multipolarity into a doctrinal vision to be instituted in policy and actively promoted abroad. The 1997 National Security Concept, for example, states that Russia's interests "require active foreign policy aimed at strengthening Russia's positions as a great power - one of the influential centres in the emerging multipolar world" (Russian Federation, 2002 [1997], p. 55). At the international level, multipolarity was anchored in the Russian-Chinese Joint Declaration on a Multipolar World and the Establishment of a New International Order (Yeltsin \& Zemin, 1997).

To discern the cultural logics underlying Russia's internet governance agenda, it is necessary to appreciate continuities in ideas and policies between Kozyrev's and Primakov's tenures. Scholars commonly credit Primakov as the progenitor of Russia's multipolarity vision (e.g., Ambrosio, 2005, pp. 66-67; Clunan, 2014, p. 286; Lo, 2015, pp. 43-44; Makarychev \& Morozov, 2011, p. 355; Silvius, 2017, p. 82). The current Russian leadership, too, has mythologised Primakov as the founding father of post-Soviet Russia's foreign policy and specifically of multipolarity as its ideational basis (e.g., Putin, 2019; Lavrov, 2019). As I discuss next, however, elite imaginaries of Russia's greatness and of multipolarity informed Russian global communication diplomacy from the height of Westernism in the early 1990s to the maturation of Statism by the close of the decade.

\section{THE GENESIS OF RUSSIA'S DIGITAL MULTIPOLARITY IN THE YELTSIN YEARS, 1992-1999}

Russia's internet governance agenda that arose during Putin's presidency in the 2000s-10s drew upon the multipolarity framework that emerged during Boris Yeltsin's presidency. Russian diplomacy already advanced state-based governance of digital technologies in the 1990s in the debates over the future of global telecommunication and international information security at the International Telecommunication Union and the United Nations. This section illustrates 
how Russian policymaking discourse in these debates relied on the principles and repertoires of multipolarity.

\section{PRESERVATION OF STATE-BASED TELECOMMUNICATION GOVERNANCE AT THE ITU}

The International Telecommunication Union was established in 1865 as the International Telegraph Union to coordinate transnational telegraphy (Fari, 2015). As new technologies such as telephony, radio, and satellite appeared, the ITU incorporated them into its mandate (Balbi \& Fickers, 2020; Codding, 1995). In keeping with this tradition, from the 1970s through the early 1990s, the ITU strove-but ultimately failed-to become the global authority in data networking development and governance (Schafer, 2020; Rioux et al., 2014; Winseck, 2020). In the closing decade of the twentieth century, global trends of economic liberalisation and technological convergence spurred the debate within the ITU about enhancing the role of the private sector in its operations and about the Union becoming the worldwide champion of telecommunication development and liberalisation (Hills, 2007, Ch. 4). The potential changes were debated and subsequently instituted at the three ITU Plenipotentiary conferences, which took place in Geneva in 1992, Kyoto in 1994, and Minneapolis in 1998 ("ITU Plenipotentiaries", 1993; MacLean, 1995, 1999). Russian delegations at the Plenipotentiaries applied to the telecommunication domain multipolarity's foundational propositions of Russia's greatness, preeminence of states and multilateral organisations in global governance, and all countries' equal access to global governance.

The Russian state's approach to global communication and internet governance reflects its ruling elites' conceptions of Russia and its place in the world. In the early 1990s, Russian diplomacy presented the country as at once a new liberal democracy and a historic great power. Accordingly, the Russian delegate at the Plenary Meeting of the Geneva Plenipotentiary in December 1992 portrayed the country simultaneously as a first-time ITU participant and as one of the organisation's founding members: "This is the first time that a delegation from the Russian Federation is taking part in a Plenipotentiary Conference of the International Telecommunication Union. It will be remembered, however, that Russia was one of the 20 founder States of the Union at the Paris Conference 127 years ago" (Russian Federation, 1992b). Russia's proposed liberal and great power identities in their respective ways were meant to bolster the country's legitimacy in global telecommunication governance.

Russia's dual identity narrative at the ITU obscured the country's continuities with the Soviet period while emphasising the relation to its past as an imperial great power. Over a third of the Russian delegation's members at the 1992 Plenipotentiary, including the most senior diplomats, had represented the Soviet Union at the previous Plenipotentiary in 1989 (International Telecommunication Union, 1989 , pp. 66-67; 1993, pp. 40-42). Against these material continuities with the ancien régime, introducing the Russian delegation as a first-time participant signalled the Russian state's symbolic rejection of communism, to recall Kozyrev's wording, and its aspiration to membership in the liberal community. In the atmosphere of postCold War liberal triumphalism, Russia's alignment with the liberal camp and self-presentation as one of the victors of the Cold War served as justification for its equal role in global governance.

Like Russia's appeal to its liberal identity, its delegation's invocation of the Russian Empire's critical role in the ITU's inception in the nineteenth century also was meant to render presentday Russia's voice credible in the debate about the Union's operations. The Russian Empire was one of the International Telegraph Union's twenty founding members in 1865 and played a 
prominent role in its work, including hosting the Union's 1875 conference in Saint Petersburg. In the decades following Russia's devastating loss to the Euro-Ottoman coalition in the Crimean War (1853-56), Russia viewed its active involvement in governing global telegraphy as contributing to the restoration of its great power prestige and conveying its belonging within the civilised European community (Siefert, 2020). Russia's great power imaginary, then, has shaped the logics of its telecommunication diplomacy across centuries.

Whereas in the nineteenth century a country's partaking in the then-novel domains of international law and multilateral diplomacy signified its enlightened modern nature, the late twentieth century neoliberal culture framed support for state-based governance as retrograde. In the prevailing climate of privatisation of governance, Russia was under pressure to legitimise its state-centric agenda. Tellingly, at the 1992 Geneva Plenipotentiary, the Russian delegate insisted that Russia was "in favour of progressive reforms and against conservatism", but that its caution against privatisation was meant to ensure that the conference's decisions ultimately increased the ITU's efficiency (Russian Federation, 1992b).

In endorsing continued centrality of national governments at the ITU, Russia appealed to the ITU's own tradition of state-based governance and to the purported fact that states' own interests were best served by the existing state-based governance model. Russian proposal for the work of the 1992 Geneva conference, for example, argued that it is "desirable to maintain some historical continuity and draw on the practical experience accumulated by this venerably old international organisation" in sustaining the pre-existing "role and responsibility of ITU Member countries" (Russian Federation, 1992a, p. 1). While acknowledging the non-state actors' technical contributions, the proposal invoked ITU traditions in reminding member nations that, "[n]evertheless, it has always been the Administrations of the Member countries of the Union which have [...] exercised a leading role" at the ITU (Ibid., p. 3). Put simply, Russia argued that something that wasn't broken didn't require fixing.

In addition to a historical argument, the proposal alleged that maintaining the primacy of national governments at the ITU would reflect the supposed international consensus that saw state-based governance as preferable. The document contended that "all countries" recognised telecommunications' "significance for safeguarding [state] interests at the international level" and therefore "[gave] the State a key say in the management of telecommunications as a whole" (Ibid., p. 3). In conclusion, the document reiterated that the ITU Constitution and Convention, which were being finalised at the Geneva conference, needed to " $[\mathrm{m}]$ aintain and consolidate the leading role and responsibility of Administrations in the work of the ITU, which is an intergovernmental specialised agency of the United Nations" (Ibid., p. 3). At the following 1994 Plenipotentiary in Kyoto, the Russian delegation headed by the Minister of Posts and Telecommunications Vladimir Boulgak (1990-1997) continued calling for "preserving each State's sovereign right to manage its own telecommunications" (Boulgak, 1994) as well as for "preserving the ITU's pre-eminent world role in the regulation of international telecommunication issues" (Russian Federation, 1994a, p. 4).

The key promise of state-based multilateral governance, according to the Russian multipolarity narrative, is countries' equal participation in world affairs. To this end, in the 1990 s Russia lobbied for the United Nations system's historical principle of equitable geographic distribution to be officially instituted at the ITU. The principle professes fair distribution of bureaucratic functions among the organisation's five administrative world regions: the Americas, Western Europe, Eastern Europe and North-eastern Asia, Africa, and Asia and Australasia (Thakur, 1999). In practice, however, distribution of higher-level posts at the ITU historically skewed in 
favour of the developed West. At the 1994 Plenipotentiary, Russia framed its support for making the principle of equitable geographic distribution mandatory in multipolarity terms of egalitarian global governance: "so that the representatives of the various countries - whether developed or developing, large or small - enjoy equal access to [the ITU administrative] duties" (Russian Federation, 1994b, n.p., RUS/11/7 (MOD) 20-22). Russia's proposal did not garner enough support in 1994 and was put aside.

At the 1998 Plenipotentiary, Russia warned that failure to uphold the principle of equitable geographic distribution would have "a significant moral and psychological impact which can ultimately affect the effectiveness of the ITU activity" (Russian Federation, 1998, p. 7, RUS/34/17 (MOD) 20-22). Russia insinuated that the absence of equitable geographic distribution (i.e., unipolarity) is not simply immoral, but also inefficient in the long run. Further, Russia's 1998 proposal decried the fact that because the previous conference had not mandated the principle of equitable geographic distribution, representatives of Asian and Eastern European administrative regions, "which account for more than two-thirds of the world's population and have enormous economic, technical and intellectual potential have been deprived of elected posts" (Ibid.). As a country that belongs to the ITU's administrative region of Eastern Europe, Russia was lamenting foremost its own exclusion from this facet of global governance - the very problem that its pursuit of multipolarity was seeking to resolve. Not coincidentally, the Russian proposal's sentiment regarding the excluded Asian and Eastern European countries' constructive potential and desire for participation in telecommunication governance closely resembles how the 1993 Russian Foreign Policy Concept articulates one of Russia's primary national tasks: "to achieve the equal and natural incorporation of the Russian Federation into the world community as a great power that boasts a centuries-long history, unique geopolitical situation, considerable military might, and significant technological, intellectual and ethical capacities" (Russian Federation, 2005 [1993], p. 27). Russia's obscuring of its national interests in the selfless language of international equity is a reminder that, ultimately, Russia's pursuit of multipolarity is guided by its desire for full participation in global governance as a recognised great power.

\section{PROMOTION OF STATE-BASED INTERNATIONAL INFORMATION SECURITY AT THE UNITED NATIONS}

The repertoires of multipolarity advanced at the ITU also informed Russia's pioneering of the international information security issue at the UN in 1998-99. In a September 1998 letter to the UN Secretary-General Kofi Annan, Russian Foreign Minister Igor Ivanov (1998-2004) urged the international community to place international information security atop the UN agenda (Ivanov, 1998). The letter contained an accompanying draft resolution entitled Developments in the field of information and telecommunications in the context of international security. The two-page resolution, which the UNGA adopted with minor changes, drew attention to the potential malicious use of emerging scientific-technological innovations, encouraged promotion of the consideration of this issue at the international level, and invited UN member states to submit their views on the subject (United Nations General Assembly, 1999). Since 1998, Russia has resubmitted the resolution annually, and the General Assembly has readopted it each time (United Nations Office for Disarmament Affairs, n.d.).

Russia's resolution over the years contributed to the institutionalisation of internet geopolitics. In August 1999, citing the resolution as its impetus, the UN convened the first forum on international information security, bringing together dozens of high-level governmental and non-governmental experts from around the globe to discuss the issue (United Nations Institute for Disarmament Research, 1999). Further, at the resolution's suggestion, states began sharing 
their views on international information security with the Secretary-General. These are collected and published annually under the auspices of the UN and serve as an ongoing intergovernmental discussion platform on the subject (United Nations Office for Disarmament Affairs, n.d.).

Another major outgrowth of the resolution was the Group of Governmental Experts on Developments in the Field of Information and Telecommunications in the Context of International Security (GGE) (United Nations Office for Disarmament Affairs, 2019). First suggested by the 2002 resolution, GGE were a series of year-long consultations on cybersecurity norms among up to two dozen national delegations that became a crucial venue for intergovernmental deliberations. Between 2004 and 2017, GGE processes took place five times and produced three expert reports that demonstrated gradual progress in achieving intergovernmental understanding on the foundations of international information security. In 2017, GGE split into two parallel discussion processes spearheaded by the USA and Russia (Henriksen, 2019).

Russia's promotion of state-based information security governance at the UN in 1998-99 must be understood within the period's geopolitical context. In the fall of 1998, after two years of Primakov leading the Russian foreign policy, Russia-West relations were generally cooperative, even if the Kozyrev-era language of Russia's Euro-Atlantic integration and shared liberal destiny had by then subsided. Weeks before Russia introduced the issue at the UN in 1998, for instance, the presidents of Russia and the USA signed a Joint Statement on Common Security Challenges at the Threshold of the Twenty-First Century. Calling Russia and the USA "natural partners in advancing international peace and stability," the statement identified "mitigating the negative aspects of the information technology revolution" and counteracting "computer and other hightechnology crime" among multiple areas for the two countries' potential cooperation (Clinton \& Yeltsin, 1998). Moreover, following the devastating financial crisis that hit Russia in mid-August 1998, the Russian leadership was particularly eager to assuage Western fears of their country's illiberal turn in the face of economic hardship. As Igor Ivanov emphatically argued in his Plenary address at the UNGA:

\section{From this rostrum I pledge that Russia will not deviate from the path of reform and will do its best to pass with dignity this most difficult test, so as not only to preserve the democratic progress that has been made but also to augment it.}

Likewise, Russia's foreign policy will remain consistent and constructive. It is firmly geared towards building a democratic multipolar world[.] (Ivanov, 1998, p. 20)

Ivanov's remarks reveal that at the time Russian elites did not view their public commitment to furthering domestic liberalisation, which had begun in the early 1990s, as incongruent with the multipolarity stance in foreign policy.

The original 1998 and subsequent annual draft resolutions on international information security submitted by Russia conveyed its longstanding preference for multilateral global governance. The text of the 1998 resolution called on the international community to promote the issue of information threats at "multilateral levels" and tackle them by "developing international principles" that would enhance global ICT security (United Nations General Assembly, 1999). Russia's decision to advance the issue of information security via the UN is itself telling of Russia's normative view of the UN as the preeminent governance venue in a multipolar world. 
In fact, Russia framed its push to institutionalise information security within the UN expressly in terms of increasing the UN's efficiency. In his UNGA address in 1998, after voicing Russia's support for "reforms and changes in United Nations mechanisms that will promote effective consolidation of the United Nations and improve its activities," Ivanov indicated that "Russia's initiative to launch a discussion on ways to achieve international information security serves the same goal" (Ivanov, 1998, p. 23; added emphasis).

The 1998 resolution portrayed the latest information and telecommunication technologies as the world's shared good that ought to be protected from nefarious use. Responsible use of information technologies, according to the text, furthered the "development of civilization", created opportunities for the "common good of all States", enhanced the "creative potential of mankind", and improved the "circulation of information in the global community" (United Nations General Assembly, 1999). The all-embracing tropes-civilization, common good, all states, mankind, global community-drew on Russia's framing of multipolarity as the egalitarian peaceful order that benefits all countries contrasted with the allegedly conflict-ridden unipolarity that benefits the hegemon alone. When introducing the second iteration of the resolution in the fall of 1999, Russia's representative Anatoly Antonov, who later served as the country's ambassador to the United States, insisted that the document was "exclusively nonconfrontational and cover[ed] the interests of a broad range of States” (Antonov, 1999, p. 13).

The 1998 resolution called on world governments to share their views on international information security. In August 1999, the UN Secretary-General published the inaugural collection of countries' replies to that call (UN Secretary-General, 1999). Russia's contribution to the report was steeped in the logics of multipolarity, detailing its vision of the geopolitical role of information technologies, the primary threats stemming from their misuse, and the required measures for containing these potential dangers. At the outset, Russia's entry expressed concern that states' use of information technologies for enhancing their military capabilities "alter[ed] the global and regional balance of forces and g[ave] rise to tension between traditional and emerging centres of power and influence" (UN Secretary-General, 1999, p. 8). This shifting landscape, the entry alleged, could lead to growing non-compliance with "the principles of the sovereign equality of States" and of "non-interference in internal affairs" - the existential conditions for Russia's own survival and for the functioning of the multipolar world, according to Russian foreign policy discourse (Ibid.).

Russian ruling elites evidently feared the post-Cold War geopolitical balance would tilt further in favour of the most developed powers that could afford to employ the latest information technologies to their strategic advantage, foremost the United States. Given that Russia lacked equivalent resources that would allow it to partake in the scientific-technological race, an unconstrained technological competition would compromise its great power status. As Russia saw it, at the time, "international law ha[d] virtually no means of regulating" such information weaponry (Ibid.). Hence, the document went on to identify potential dangers arising from the misuse of information technologies and to propose solutions for their amelioration.

Russia's entry defined information security as "including the information and telecommunications infrastructure and information per se" (Ibid., p. 10). That definition signalled Russia's understanding of the concept as encompassing both hardware and content. Definitions given to the internet and associated technologies shape their design and governance by framing the issues and designating the actors responsible for their solutions (DeNardis, 2020, pp. 189-191). Russia's expansive socio-technical understanding of information security means that it views information technologies' material (infrastructure) and symbolic 
(information) dimensions as falling within the ambit of state regulation domestically and internationally. Russia's opponents, chiefly Western liberal democracies, privilege a limited technical understanding of information security as pertaining to ICT infrastructures alone and critique Russia's approach for giving the state a carte blanche for undue content control (Giles \& Hagestad II, 2012; Godwin III et al., 2014).

In line with Russia's two-pronged understanding of information security, its 1999 contribution to the collection of replies warned against states' adversarial actions at material and symbolic levels of information technologies. Expressing the Kremlin's proclaimed support for states' domestic independence and criticism of the US geopolitical domination, the document cautioned that some states may seek to "dominate and control" the information realm and to acquire a "monopoly" over other countries' informational capabilities, rendering them "technologically dependent" (UN Secretary-General, 1999, p. 9). Specifically, the document noted the dangers of "[u]ncontrolled transboundary dissemination of information" and "[m]anipulation of information flows" aimed at undermining "a State's political and social system" and eroding its population's "traditional cultural, moral, ethical and aesthetic values" (Ibid.). These warnings are an early example of post-Soviet Russia's explicit opposition to the free flow of information doctrine and support for nationally bounded information segments, which would form the crux of Russia's global internet governance vision in the following decades.

To safeguard the world against varied information threats, Russia's entry advocated relying on multilateral diplomacy and international law. As usual, Russia painted such multilateral governance as the system that took into account all countries' interests, unlike the egoistic unipolar system. Russia's entry suggested locating "all existing positions and views" on information security in order to identify countries" "common approaches" that would underlie "a multilateral international legal instrument” to regulate this domain (Ibid.). For its part, Russia proposed a number of state-centric initiatives for "an international legal basis" of information security, reflecting its preference for binding intergovernmental agreements as a key digital governance mechanism.

In light of the resolution's relative prominence within the international policymaking community, Russian diplomats over the past two decades often have invoked the document to portray Russia as a pioneering internet governance power whose efforts to reshape the global internet order enjoyed widespread support and, therefore, legitimacy (e.g., Boyko, 2016; Medvedev, 2015; Russian Ministry of Foreign Affairs, 2008, pp. 26-27). As early as in October 1999, Russia's delegate at the UN, Anatoly Antonov, reminded his colleagues that the previous year "Russia for the first time took the initiative of introducing a draft resolution" that evolved into the "discussion initiated by the Russian Federation of an important and topical issue - the problem of information security" (Antonov, 1999, p. 12, added emphasis). Like the reference to Russia's status of an ITU co-founder at the 1992 ITU Plenipotentiary, Antonov's words were meant to confer historical credibility upon Russia's state-centric position on international information security by portraying Russia as a progenitor of this very geopolitical issue.

Russia's approach to global communication that formed throughout both liberal and statist foreign policy orientations in the 1990s then informed its global internet governance agenda during Vladimir Putin's rule in the 200os-10s; this despite the fact that the Putin's regime has constructed its image in explicit opposition to Russia's liberal period. From the early 200os, the Kremlin has legitimised the regime's growing authoritarianism with the narrative that Putin's assertive policies helped Russia overcome “the turbulent 1990s", including the country's alleged 
subservience to the West and loss of international prestige, and enjoy "the stable 200os" (Malinova, 2020). By illuminating how the current administration's digital multipolarity philosophy, in fact, ultimately draws upon Kozyrev-era multipolarity discourse, the next section further highlights the essential role of historical identity narratives in understanding Russia's internet governance.

\section{RUSSIA'S DIGITAL MULTIPOLARITY AND GLOBAL INTERNET GOVERNANCE IN THE TWENTY-FIRST CENTURY}

Since the internet's emergence in the 1970s under the auspices of the US Department of Defence, its design and governance have been subject to negotiations and power struggles among public and private actors within the United States and internationally (Abbate, 1999; Braman, 2011, 2012; Russell, 2014, Ch. 8). Following the internet's rapid popularisation and commercialisation of the mid-1990s, internet governance was quickly acquiring a geopolitical dimension (Braman, 2004; Paré, 2002). At the time, multiple world powers called for placing the internet under an international rule. Instead, in order to secure the US government's historical privilege over the now ascendant technology, the White House facilitated placing the US-based non-governmental technical bodies in charge of the global internet's critical resources and standards (Mueller, 2002).

In response to the novel US-centric internet governance arrangement to the exclusion of the international community, the 1998 ITU Plenipotentiary proposed convening an international forum to discuss socio-political aspects of digital technologies (Kleinwächter, 2004). The resulting two-phase event, the World Summit on Information Society (WSIS), took place under the auspices of the UN in 2003 and 2005. Attended by over 11,000 participants, including dozens of heads of states and ministers, WSIS signalled the expansion of internet governance from the technical niche into a standalone public policy domain (Mueller, 2010, Ch. 3).

WSIS elevated multistakeholderism as the foundational principle of internet governance. The ideal of multistakeholderism promises egalitarian distribution of governing functions among governmental and non-governmental stakeholders while casting state-based governance as non-democratic. In practice, digital corporations and major states dominate internet policymaking relative to civil society actors and less powerful governments, thereby reinforcing existing power imbalances rather than leveling the internet governance field (Hofmann, 2016; Radu et al., 2014, Part 2). As a home to the global internet's critical infrastructures and largest digital corporations, the United States are the primary beneficiary of the multistakeholder status quo (Powers \& Jablonski, 2015).

In the lead-up to the WSIS and thereafter, Russia promoted state-centric internet multilateralism in opposition to the multistakeholder model. In his Plenary addresses at both phases of the WSIS, the Minister for Information Technologies and Communications Leonid Reiman (1999-2008) emphasised Russia's view that states via the UN and the ITU should play the leading role in governing the global information society with the secondary consultative roles reserved for the private sector and other stakeholders (Reiman, 2003, 2005). In the years since the WSIS, the multipolarity framework has continuously informed Russia's increasingly assertive promotion of this state-centric internet governance hierarchy. At the inaugural International Cybersecurity Congress in Moscow in 2018, a high-profile annual conference 
organised by Russia's largest state-affiliated bank Sberbank, Putin argued for the need

[T] o develop common rules of the game and binding international standards [for
cyberspace] that will take into account the rights and interests of all countries as
much as possible and will be universal and acceptable for all. We have seen more
than once that some countries' egoism and self-centred policies are damaging the
international information stability.

[...] I would like to say that Russia has advanced a number of initiatives on the rules of responsible behaviour of states in the information sphere, legal mechanisms for fighting cybercrime and international internet governance.

We intend to continue to promote these initiatives, primarily at the most highly respected and influential international organisation, the UN. (Putin, 2018)

Putin's remarks conveyed key propositions of Russia's multipolarity narrative. In line with multipolarity's critique of the unipolar system as innately unstable and prone to conflict, Putin determined instability of the international information environment as the primary issue that internet governance should address. The Russian president identified the egoism of the United States, referred to with a thinly veiled euphemism of "some countries", as the root cause of this instability. Putin's proposed mechanisms for tackling the instability included state-based multilateralism and international law, particularly the time-tested United Nations. According to the statement, Russia's state-centric approach, by contrast with the US egoism, respected the rights and interests of all countries. In appealing to the UN history and to states' own interests, Putin's remarks mirrored Russia's two-pronged argument for state-based governance at the ITU in 1992-94, which had similarly referred to the ITU's tradition and an alleged preference of all countries for the state-based status quo. Drawing on another long-standing trope of Russian global communication diplomacy that hails Russia's role within policymaking debates, Putin portrayed Russia as a key internet power by reminding about its past and future internet governance initiatives.

Russia institutionalised its digital multipolarity narrative at the international level through proliferating internet governance initiatives with allied governments. The two primary organisations that have aided Russia's international advancement of digital multipolarity have been BRICS (Brazil, Russia, India, China, and South Africa) and the Shanghai Cooperation Organisation (SCO) consisting of China, Kazakhstan, Kyrgyzstan, Russia, Tajikistan and Uzbekistan, and since 2017 also India and Pakistan. In 2011 and 2015, for example, SCO members proposed the International code of conduct for information security to the UNGA (Li et al., 2011; Liu et al., 2015). This non-binding set of principles for regulating states' behaviour in cyberspace called for "the establishment of multilateral, transparent and democratic international Internet governance mechanisms," among other reforms (Liu et al., 2015, p. 5). The proposal equated multilateral internet governance with transparency and democracy, while implying that it is the current system of unilateral US-based internet governance that is nondemocratic and non-transparent for its lack of accountability to the international community. In another instance, after gathering upon Russia's initiative in 2015, BRICS communication ministers reasserted "the right of all States to establish and implement policies for information and communication networks in their territories in accordance with their respective history, culture, religion and social factors" (BRICS, 2015). Echoing Russia's rhetoric during the UN international information security debates in the late 1990 s about the need to protect states' political systems and traditional values, the BRICS communique argued for aligning countries' 
informational and territorial borders to protect states' domestic sovereignty and, consequently, global political and cultural diversity.

With the deterioration of Russia-West relations in the recent years, Russian official rhetoric toward the West has become increasingly hostile while maintaining multipolarity's longstanding claims and metaphors (e.g., Putin, 2013; Lavrov, 2017). In late 2018, the Russian Foreign Ministry issued a strongly worded condemnation of liberal democracies for not supporting Russia's internet governance initiatives at the UNGA that year. The official statement argued that in opposing Russia's internet multilateralism "the Western countries have set themselves off against the international community" and "have only their own mercenary goals in mind" (Russian Ministry of Foreign Affairs, 2018). The statement's rhetoric was more confrontational toward the West than Russia's multipolarity narrative in the 1990s. At the same time, it advanced digital multipolarity's decades-old foundational repertoires in arguing that "all countries, regardless of their level of technological development, have a right to take a direct part in talks on [international information security] at the UN and to influence the decisionmaking process," and that only such egalitarian governance can foster "a fair and equal world order in the digital sphere" (Ibid.). Two decades prior at the ITU Russia advanced a similarly worded argument in support of the principle of equitable geographic distribution of posts.

\section{CONCLUSION: TOWARD A CULTURAL FRAMEWORK OF INTERNET GOVERNANCE}

This essay explored the cultural logics underpinning the Russian state's geopolitical pursuit of multilateral internet governance. Over the past two decades, Russia has emerged as a leading advocate of transferring the global internet's key governing functions and infrastructures away from the ambit of non-governmental organisations historically tied to the US public and private sectors toward state-based international organisations, such as the United Nations and its specialised agency, the International Telecommunication Union. Since Russia's internet governance activism arose during Vladimir Putin's rule in the 2000s-10s, most scholars have interpreted Russia's global internet agenda as an expression of Putin's regime characterised by increasing authoritarianism and anti-Western illiberalism.

In this article, I offered an alternative analytical lens to argue that Russian ruling elites' perception of Russia as a historic great power with an inherent right to full participation in global governance has directed the Russian state's approach to global internet governance-what I conceptualised as digital multipolarity. As a self-perceived great power, Russia has viewed the US-led unipolar order that emerged in the post-Cold War environment as curtailing its domestic sovereignty and historical role in managing the international system. Consequently, from its first months of post-Soviet independence, Russia has advanced the normative idea of a multipolar world order that would be based on the pre-eminence in global governance of the United Nations and its Security Council.

To illuminate how Russian elites' great power and multipolarity imaginaries continuously have underlain its digital multipolarity advocacy from enthused liberalism of the early 1990 s to vehement illiberalism in the second half of the 2010s, I examined two sets of Russian policymaking initiatives in the 1990s. Each of the two initiatives is rooted in the logics and language of multipolarity. One is Russia's defence of the ITU's internal state-based governance and the Union's leading role in global telecommunication governance. Another is Russia's 
promotion of state-based international information security at the UN. By delimiting the crux of my analysis to Russia's first post-Soviet decade, I disentangled Russia's political developments under Putin's rule from the great power imaginary that had informed Russian foreign policy for centuries.

My focus on the ideational factors shaping the Russian state's internet governance philosophy does not negate the Kremlin's instrumental use of information policy and digital technologies to promote its geopolitical agenda and exert greater social and political control at home. I have shown, rather, that cultural frameworks, such as elites' ingrained ideas about the country's national identity and place in world history and contemporary politics, can shape states' global communication agenda across political regimes and ideologies. 


\section{REFERENCES}

Abbate, J. (1999). Inventing the internet. MIT Press.

Ambrosio, T. (2005). Challenging america's global preeminence: Russia's quest for multipolarity. Routledge. https://doi.org/10.4324/9781315260686

Antonov, A. (1999). UN general assembly 54th session. 16th Meeting, UN First Committee (A/C.1/54/PV.16), 12-13. https://undocs.org/en/A/C.1/54/PV.16

Balbi, G., \& Fickers, A. (Eds.). (2020). History of the International Telecommunication Union (ITU): Transnational techno-diplomacy from the telegraph to the Internet. In History of the International Telecommunication Union (ITU). De Gruyter.

https://doi.org/10.1515/9783110669701

Boulgak, V. (1994). Statement by the head of the delegation of the russian federation dr. Vladimir boulgak. Minutes of the First Plenary Meeting (Document 83-E), 1994 ITU Plenipotentiary Conference, 16-17.

http://search.itu.int/history/HistoryDigitalCollectionDocLibrary/4.15·51.en.101.pdf

Boyko, S. (2016). UN Group of Governmental Experts on Developments in the Field of Information and Telecommunications in the Context of International Security: A View from the Past into the Future (Gruppa pravitel $\square$ stvennykh èkspertov OON po dostizhenii $\square$ am v sfere informatizat $\square$ sii i telekommunikat $\square$ siǔ v kontekste mezhdunarodnor̆ bezopasnosti: Vzgli $\square$ ad iz proshlogo v budushchee). International Affairs (Russia), 8.

https://interaffairs.ru/jauthor/material/1718

Braman, S. (Ed.). (2004). The emergent global information policy regime. Palgrave. https://doi.org/10.1057/9780230377684

Braman, S. (2011). The framing years: Policy fundamentals in the internet design process, 1969-1979. The Information Society, 27(5), 295-310.

https://doi.org/10.1080/01972243.2011.607027

Braman, S. (2012). Internationalization of the Internet by design: The first decade. Global Media and Communication. https://doi.org/10.1177/1742766511434731

B.R.I.C.S. (2015). Communique of BRICS ICT Ministers on results of the meeting "Expanding of collaboration in spheres of telcom and infocommunications" [Official statement]. Minisistry of Digital Development, Communications and Mass Media of the Russian Federation.

https://digital.gov.ru/en/events/34194/

Brousseau, E., Marzouki, M., \& Méadel, C. (Eds.). (2012). Governance, regulation and powers on the internet. Cambridge University Press.

Bygrave, L. A., \& Bing, J. (Eds.). (2009). Internet governance: Infrastructure and institutions. Oxford University Press. https://doi.org/10.1093/acprof:oso/9780199561131.001.0001

Chebankova, E. (2017). Russia's idea of the multipolar world order: Origins and main dimensions. Post-Soviet Affairs, 33(3), 217-234.

https://doi.org/10.1080/1060586X.2017.1293394

Chenou, J.-M. (2014). From cyber-libertarianism to neoliberalism: Internet exceptionalism, 
multi-stakeholderism, and the institutionalisation of internet governance in the $1990 \mathrm{~s}$.

Globalizations, 11(2), 205-223. https://doi.org/10.1080/14747731.2014.887387

Chernenko, E. (2018). Russia's cyber diplomacy (No. 148; Challiot Paper, pp. 43-52). European Union Institute for Security Studies. https://www.iss.europa.eu/content/hacks-leaks-anddisruptions-\%E2\%80\%93-russian-cyber-strategies

Choucri, N., \& Clark, D. D. (2019). International relations in the cyber age: The co-evolution dilemma. The MIT Press.

Claessen, E. (2020). Reshaping the internet - the impact of the securitisation of internet infrastructure on approaches to internet governance: The case of Russia and the EU. Journal of Cyber Policy, 5(1), 140-157. https://doi.org/10.1080/23738871.2020.1728356

Clinton, W. J., \& Yeltsin, B. (1998). Joint statement on common security challenges at the threshold of the twenty-first century. https://www.govinfo.gov/content/pkg/WCPD-1998-0907/pdf/WCPD-1998-09-07-Pg1696.pdf

Clunan, A. L. (2014). Historical aspirations and the domestic politics of Russia's pursuit of international status. Communist and Post-Communist Studies, 47(3), 281-290.

https://doi.org/10.1016/j.postcomstud.2014.09.002

Codding, Jr, G. A. (1995). The International Telecommunication Union: 130 years of telecommunications regulation. Denver Journal of International Law and Policy, 23(3), 501-512. https://digitalcommons.du.edu/djilp/vol23/iss3/3/

Deibert, R. J., \& Crete-Nishihata, M. (2012). Global governance and the spread of cyberspace controls. Global Governance, 18(3), 339-361. https://doi.org/10.1163/19426720-01803006

DeNardis, L. (2014). The global war for internet governance. Yale University Press. https://doi.org/10.12987/yale/9780300181357.001.0001

DeNardis, L. (2020). The internet in everything: Freedom and security in a world with no off switch. Yale University Press.

Dumitrica, D. (2015). Imagining the canadian internet: A case of discursive nationalization of technology. Studies in Ethnicity and Nationalism, 15(3), 448-473.

https://doi.org/10.1111/sena.12152

Ebert, H., \& Maurer, T. (2013). Contested cyberspace and rising powers. Third World Quarterly, 34(6), 1054-1074. https://doi.org/10.1080/01436597.2013.802502

Fari, S. (2015). The formative years of the telegraph union. Cambridge Scholars Publishing.

Federation, R. (1994a). Proposals for amendments to the Constitution and Convention of the ITU. http://search.itu.int/history/HistoryDigitalCollectionDocLibrary/4.15.51.en.101.pdf

Federation, R. (2002). National security concept (1997: Vol. IV (T. Shakleina, Ed.; pp. 51-74). Moscow State Institute of International Relations.

Federation, R. (2005). Foreign policy conception of the russian federation (1993. In A. Melville \& T. Shakleina (Eds.), Russian foreign policy in transition: Concepts and realities (pp. 28-64). Central European University Press. 
Federation, R. (1994b). Draft resolution [RUS/2]: Possible ways of improving the efficiency of ITU's work. Proposals for the Work of the Conference (Document 47-E, 4-6.

http://search.itu.int/history/HistoryDigitalCollectionDocLibrary/4.15.51.en.101.pdf

Federation, R. (1992). Statement by the delegate of the Russian Federation. Minutes of the First Plenary Meeting (Document 77 (Rev.1)-E), 1992 ITU Additional Plenipotentiary Conference, Annex 3, 13.

http://search.itu.int/history/HistoryDigitalCollectionDocLibrary/4.14.51.en.101.pdf

Franke, U., \& Pallin, C. V. (2012). Russian Politics and the Internet in 2012 (FOI-R--3590--SE). FOI: Swedish Defence Research Agency. https://www.foi.se/report-

search/pdf?fileName=D\%3A\%5CReportSearch\%5CFiles\%5Cebbo43f5-26fc-41be-982b-da5893 98eeb7.pdf

Freedman, L., \& Wilkinson, B. (2013). Autocracy rising: The internet in a multipolar world. Index on Censorship, 42(2), 59-61. https://doi.org/10.1177/0306422013492258

Gel'man, V. (2015). Authoritarian russia: Analyzing post-soviet regime changes. University of Pittsburgh Press.

Giles, K., \& Hagestad, W. I. (2013). Divided by a common language: Cyber definitions in chinese, russian and english. 5th International Conference on Cyber Conflict (CyCon) Proceedings, 413-429. https://ccdcoe.org/uploads/2018/10/CyCon_2013_Proceedings.pdf

Gill, R. (2018). Discourse. In M. Kackman \& C. Kearney (Eds.), The craft of criticism: Critical media studies in practice. Routledge. https://doi.org/10.4324/9781315879970-3

Godwin, III, J. B., Kulpin, A., \& Rauscher, K. F. (2014). Critical terminology foundations 2: Russia-U.S (Policy Report No. 2/2014). The EastWest Institute; Information Security Institute, Moscow State University. https://www.files.ethz.ch/isn/178418/terminology2.pdf

Henriksen, A. (2019). The end of the road for the UN GGE process: The future regulation of cyberspace. Journal of Cybersecurity, 5(1). https://doi.org/10.1093/cybsec/tyyoo9

Hills, J. (2007). Telecommunications and Empire. University of Illinois Press.

Hofmann, J. (2016). Multi-stakeholderism in Internet governance: Putting a fiction into practice. Journal of Cyber Policy, 1(1), 29-49.

https://doi.org/10.1080/23738871.2016.1158303

International Telecommunication Union. (n.d.). Plenipotentiary conference (Geneva, 1959). http://handle.itu.int/11.1004/020.1000/4.9

International Telecommunication Union. (1989). List of participants, 1989 plenipotentiary conference. International Telecommunication Union; ITU Library \& Archives. http://search.itu.int/history/HistoryDigitalCollectionDocLibrary/4.13.44.m7.10o.pdf International Telecommunication Union. (1993). List of participants, 1992 additional plenipotentiary conference. International Telecommunication Union; ITU Library \& Archives. http://search.itu.int/history/HistoryDigitalCollectionDocLibrary/4.14.44.m7.10o.pdf

ITU Plenipotentiaries agree on a new ITU. (1993). Telecommunication Journal, 6o(2), 55-62. http://search.itu.int/history/HistoryDigitalCollectionDocLibrary/4.14.57.en.101.pdf 
Ivanov, I. (1998a). UN general assembly 53rd session. United Nations; United Nations Official Records. https://undocs.org/en/A/53/PV.9

Ivanov, I. (1998b). Letter dated 23 September 1998 from the Minister for Foreign Affairs of the Russian Federation addressed to the Secretary-General. https://undocs.org/en/A/C.1/53/3

Jasanoff, S., \& Kim, S.-H. (2015). Dreamscapes of modernity: Sociotechnical imaginaries and the fabrication of power. University of Chicago Press.

https://doi.org/10.7208/chicago/9780226276663.001.0001

Kennedy, D. (2013). Deciphering russia: Russia's perspectives on internet policy and governance. Global Partners Digital. https://www.gp-digital.org/wpcontent/uploads/pubs/FINAL\%20-\%2oDeciphering\%20Russia.pdf

Kiggins, R. (2012). U.S. identity, security, and governance of the internet. In S. S. Costigan \& J. Perry (Eds.), Cyberspaces and global affairs (pp. 189-202). Ashgate.

Kleinwächter, W. (2016). Beyond ICANN Vs ITU?: How WSIS Tries to Enter the New Territory of Internet Governance-Wolfgang Kleinw\%ochter. International Communication Gazette, 66(3-4), 233-251. https://doi.org/10.1177/0016549204043609

Kohl, U. (Ed.). (2017). The net and the nation state: Multidisciplinary perspectives on internet governance. Cambridge University Press.

Kolstø, P., \& Blakkisrud, H. (Eds.). (2016). The new russian nationalism: Imperialism, ethnicity and authoritarianism 200O-2015. Edinburgh University Press.

https://doi.org/10.3366/edinburgh/9781474410427.001.0001

Kozyrev, A. (1992). Provisional verbatim record of the 6 th meeting.

https://undocs.org/en/A/47/PV.6

Kozyrev, A. (1994a). The lagging partnership. Foreign Affairs, 73(3), 59-71.

Kozyrev, A. (1994b). Russia and the U.S.: Partnership is not premature, it is overdue (Rossii $\square$ a i SSHA: partnerstvo ne prezhdevremenno, a zapazdyvaet). Izvestia, 3.

Lavrov, S. (2017, December). Foreign Minister Sergey Lavrov's remarks and replies to media questions during the Government Hour in the Federation Council of the Federal Assembly of the Russian Federation. The Ministry of Foreign Affairs of the Russian Federation.

http://www.mid.ru/en/press_service/video/-/asset_publisher/i6t41cq3VWP6/content/id/299 2396

Li, B., Churkin, V., Aslov, S., \& Askarov, M. (2011). International code of conduct for information security. United Nations. https://undocs.org/en/A/66/359

Liu, J., Abdrakhmanov, K., Kydyrov, T., Churkin, V., Mahmadaminov, M., \& Madrakhimov, M. (2015). International code of conduct for information security. United Nations.

https://undocs.org/en/A/69/723

Lo, B. (2002). Russian foreign policy in the post-soviet era: Reality, illusion and mythmaking. Palgrave Macmillan. https://doi.org/10.1057/9781403920058

MacLean, D. J. (1995). A new departure for the ITU: An inside view of the Kyoto Plenipotentiary 
Conference. Telecommunications Policy, 19(3), 177-190. https://doi.org/10.1016/o308$5961(95) 00002-\mathrm{N}$

MacLean, D. J. (1999). Open doors and open questions: Interpreting the results of the 1998 ITU Minneapolis Plenipotentiary Conference. Telecommunications Policy, 23(2), 147-158.

https://doi.org/10.1016/So308-5961(98)ooo84-6

Makarychev, A., \& Morozov, V. (2011). Multilateralism, multipolarity, and beyond: A menu of Russia's policy strategies. Global Governance, 17(3), 353-373.

https://doi.org/10.1163/19426720-01703006

Malinova, O. (2020). Framing the collective memory of the 1990 os as a legitimation tool for Putin's regime. Problems of Post-Communism, 1-13.

https://doi.org/10.1080/10758216.2020.1752732

Mansell, R. (2012). Imagining the internet: Communication, innovation, and governance. Oxford University Press.

Maréchal, N. (2017). Networked authoritarianism and the geopolitics of information: Understanding russian internet policy. Media and Communication, 5(1), 29-41.

https://doi.org/10.17645/mac.v5i1.808

Maurer, T. (2011). Cyber norm emergence at the United Nations-An analysis of the UN's activities regarding cyber-security (2011-11) [Discussion Paper]. Harvard Kennedy School, Belfer Center for Science and International Affairs.

https://www.belfercenter.org/sites/default/files/files/publication/maurer-cyber-norm-dp-2011 -11-final.pdf

Medvedev, D. (2015, December 16). Address at the 2nd world internet conference. The Russian Government. http://government.ru/en/news/21075/

Miskimmon, A., \& O'Loughlin, B. (2017). Russia's narratives of global order: Great power legacies in a polycentric world. Politics and Governance, 5(3), 111-120.

https://doi.org/10.17645/pag.v5i3.1017

Morgus, R. (2018). The spread of russia's digital authoritarianism. In N. D. Wright (Ed.), AI, china, russia, and the global order: Technological, political, global, and creative perspectives (pp. 85-93). U.S. Department of Defense.

Mueller, M. (2002). Ruling the root: Internet governance and the taming of cyberspace. The MIT Press.

Mueller, M. (2010). Networks and states: The global politics of internet governance. MIT Press.

Mueller, M. (2017). Will the internet fragment?: Sovereignty, globalization and cyberspace. Polity.

Musiani, F., Cogburn, D. L., DeNardis, L., \& Levinson, N. S. (Eds.). (2016). The turn to infrastructure in internet governance. Palgrave Macmillan.

https://doi.org/10.1057/9781137483591

Neumann, I. B. (2008a). Russia as a great power, 1815-2007. Journal of International 
Relations and Development, 11(2), 128-151. https://doi.org/10.1057/jird.2008.7

Neumann, I. B. (2008b). Russia's standing as a great power, 1494-1815. In T. Hopf (Ed.), Russia’s European choice. Palgrave Macmillan. https://doi.org/10.1057/9780230612587_2

Neumann, I. B. (2016). Russia and the idea of Europe: A study in identity and international relations (2nd ed.). Routledge. https://doi.org/10.4324/9781315646336

Nocetti, J. (2015). Contest and conquest: Russia and global internet governance. International Affairs, 91(1), 111-130. https://doi.org/10.1111/1468-2346.12189

O’Hara, K., \& Hall, W. (2018). Four internets: The geopolitics of digital governance (No. 206; CIGI Papers).

https://www.cigionline.org/sites/default/files/documents/Paper\%20no.206web.pdf

Paré, D. J. (2002). Internet governance in transition: Who is the master of this domain?

Rowman \& Littlefield Publishers.

Pigman, L. (2019). Russia's vision of cyberspace: A danger to regime security, public safety, and societal norms and cohesion. Journal of Cyber Policy, 4(1), 22-34.

https://doi.org/10.1080/23738871.2018.1546884

Pohle, J., Hösl, M., \& Kniep, R. (2016). Analysing internet policy as a field of struggle. Internet Policy Review, 5(3). https://doi.org/10.14763/2016.3.412

Polatin-Reuben, D., \& Wright, J. (2014). An internet with BRICS characteristics: Data sovereignty and the balkanisation of the internet. In 4th USENIX workshop on free and open communications on the internet. FOCI'14, San Diego.

https://www.usenix.org/conference/foci14/workshop-program/presentation/polatin-reuben

Polyakova, A., \& Meserole, C. (2019). Exporting digital authoritarianism: The Russian and Chinese models (Democracy \& Disorder) [Policy Brief]. The Brookings Institution.

https://www.brookings.edu/wp-

content/uploads/2019/o8/FP_20190827_digital_authoritarianism_polyakova_meserole.pdf

Powers, S. M., \& Jablonski, M. (2015). The real cyber war: The political economy of internet freedom. University of Illinois Press.

https://doi.org/10.5406/illinois/9780252039126.001.0001

Price, M. E. (2017). The global politics of internet governance: A case study in closure and technological design. In D. R. McCarthy (Ed.), Technology and world politics. Routledge. https://doi.org/10.4324/9781317353836-7

Prizel, I. (1998). National identity and foreign policy: Nationalism and leadership in Poland, Russia and Ukraine. Cambridge University Press.

Putin, V. (2013, September 19). Meeting of the valdai international discussion club. Kremlin. http://en.kremlin.ru/events/president/news/19243

Putin, V. (2018, July 6). Plenary session of the international cybersecurity congress. Kremlin. http://en.kremlin.ru/events/president/news/57957

Putin, V. (2019, October 29). Monument to Yevgeny Primakov unveiled in moscow. Kremlin. 
http://en.kremlin.ru/events/president/news/61929

Radu, R. (2019). Negotiating internet governance. Oxford University Press.

https://doi.org/10.1093/oso/9780198833079.001.0001

Radu, R., Chenou, J.-M., \& Weber, R. H. (Eds.). (2014). The evolution of global internet governance. Springer. https://doi.org/10.1007/978-3-642-45299-4

Rebello, K. (2017). Building walls with 'BRICS'? Rethinking internet governance and normative change in a multipolar world. In A. Bower \& M. Peter (Eds.), Rising powers and global governance: Opportunities, challenges, and change (pp. 25-39). Centre for Global Constitutionalism, University of St Andrews.

http://cgc.wp.st-andrews.ac.uk/files/2017/03/CGC-Junior-Scholar-WP-Series-2017-FINAL.pdf \#page $=31$

Reiman, L. (2003). Vystuplenie ministra rossǐskoŭ federat $\square$ sii po svi $\square$ azi i informatizat $\square$ sii, glavy delegat $\square$ sii Rossiuskoŭ Federat $\square$ sii na Vsemirnoì vstreche na vysshem urovne po voprosam informat $\square$ sionnogo obshchestva L.D [Address by Minister for Communications and Informatization of the Russian Federation, Head of the Russian delegation, L.D. Reiman at the Plenary Session 1 of the World Summit on the Information Society]. International Telecommunication Union.

https://www.itu.int/net/wsis/geneva/coverage/statements/russia/ru-ru.pdf

Reiman, L. (2005, November). Text of the speech by the minister for information technologies and communication of the Russian Federation Leonid Reiman at the World Summit on the Information Society. Fourth Plenary Meeting, General Debate, World Summit on the Information Society. https://www.itu.int/net/wsis/tunis/statements/docs/g-russia/1-ru.pdf

Ringmar, E. (1996). Identity, interest and action: A cultural explanation of Sweden's intervention in the Thirty Years War. Cambridge University Press.

Ringmar, E. (2002). The recognition game: Soviet Russia against the West. Cooperation and Conflict. https://doi.org/10.1177/0010836702037002973

Rioux, M., Adam, N., \& Company Pérez, B. (2014). Competing institutional trajectories for global Regulation-Internet in a fragmented world. In R. Radu, J.-M. Chenou, \& R. H. Weber (Eds.), The evolution of global internet governance (pp. 37-55). Springer.

https://doi.org/10.1007/978-3-642-45299-4_3

Rosenbach, E., \& Mansted, K. (2019). The geopolitics of information (Defending Digital Democracy Project) [Paper]. Belfer Center for Science and International Affairs, Harvard Kennedy School. https://www.belfercenter.org/sites/default/files/2019-

08/GeopoliticsInformation.pdf

Russell, A. L. (2014). Open standards and the digital age: History, ideology, and networks. Cambridge University Press.

Russian Federation. (1992). Proposals for the work of the conference (Document 9-E). International Telecommunication Union.

http://search.itu.int/history/HistoryDigitalCollectionDocLibrary/4.14.51.en.101.pdf\#page=112

Russian Ministry of Foreign Affairs. (2008). Foreign policy and diplomatic activity of the 
Russian Federation in 2007. Russian Ministry of Foreign Affairs.

https://www.mid.ru/documents/1018o/873584/Obzor2008.doc/3d343752-7ddf-4b4f-9da2-b2 fcea7fgcda

Russian Ministry of Foreign Affairs. (2018, December 7). Press release on the adoption of a Russian resolution on international information security at the UN General Assembly. Russian Ministry of Foreign Affairs. https://www.mid.ru/ru/mezdunarodnaa-informacionnaabezopasnost//asset_publisher/UsCUTiw2pO53/content/id/3437775?p_p_id=101_INSTANCE_UsCUTiw2p O53\&_101_INSTANCE_UsCUTiw2pO53_languageId=en_GB

Schafer, V. (2020). The ITU facing the emergence of the internet, 1960s-Early 2000s. In G. Balbi \& A. Fickers (Eds.), History of the International Telecommunication Union (ITU) (pp. 321-344). https://doi.org/10.1515/9783110669701-014

Schulte, S. R. (2013). Cached: Decoding the internet in global popular culture. New York University Press.

Schwartz-Shea, P., \& Yanow, D. (2012). Interpretive research design: Concepts and processes. Routledge. https://doi.org/10.4324/9780203854907

Secretary-General, U. N. (1999). Developments in the field of information and telecommunications in the context of international security. In Report of the secretary-general (p. 13). https://undocs.org/en/A/54/213

Siefert, M. (2020). The Russian empire and the International Telegraph union, 1856-1875. In G. Balbi \& A. Fickers (Eds.), History of the International Telecommunication Union (ITU) (pp. 15-36). De Gruyter. https://doi.org/10.1515/9783110669701-002

Silvius, R. (2016). Culture, political economy and civilisation in a multipolar world order: The case of russia. Routledge. https://doi.org/10.4324/9781315665917

Soldatov, A., \& Borogan, I. (2015). The red web: The struggle between Russia's digital dictators and the new online revolutionaries. PublicAffairs.

Stadnik, I. (2019). Sovereign runet: What does it mean? [White Paper]. Georgia Tech School of Public Policy. https://www.internetgovernance.org/wpcontent/uploads/IGPWhitePaper_STADNIK_RUNET-1.pdf

Taylor, C. (2003). Modern social imaginaries. Duke University Press.

Thakur, R. C. (1999). What is equitable geographic representation in the 21st century: Report of a Seminar held by the International Peace Academy and the United. The United Nations University. https://digitallibrary.un.org/record/618091/files/equitable.pdf

Thorun, C. (2009). Explaining change in Russian foreign policy: The role of ideas in POSTSOVIET russia's conduct towards the west. Palgrave Macmillan.

https://doi.org/10.1057/9780230589964

Tolz, V. (2001). Russia. Bloomsbury Academic.

Trenin, D. (2011). Of power and greatness (P. Dutkiewicz \& D. Trenin, Eds.). New York University Press. 
Tsygankov, A. P. (2019). Russia's foreign policy: Change and continuity in national identity (5th ed.). Rowman \& Littlefield.

United Nations General Assembly. (1999). Developments in the field of information and telecommunications in the context of international security, A/RES/53/7O. United Nations. http://undocs.org/A/RES/53/70

United Nations Institute of Disarmament Research. (1999). Developments in the field of information and telecommunications in the context of international security, Geneva-25-26 August 1999. Private discussion meeting hosted by DDA and UNIDIR. United Nations. https://www.unidir.org/sites/default/files/conferences/pdfs/summary-eng-o-25.pdf

United Nations Office for Disarmament Affairs. (n.d.). Developments in the field of information and telecommunications in the context of international security. United Nations Office for Disarmament Affairs. https://www.un.org/disarmament/ict-security/

United nations office for disarmament affairs. (2019). Fact sheet: Developments in the field of information and telecommunications in the context of international security. United Nations. https://unoda-web.s3.amazonaws.com/wp-content/uploads/2019/o7/Information-SecurityFact-Sheet-July-2019.pdf

Weldes, J. (1999). Constructing national interests: The United States and the Cuban missile crisis. University of Minnesota Press.

Winseck, D. (2017). The geopolitical economy of the global internet infrastructure. Journal of Information Policy, 7, 228-267. https://doi.org/10.5325/jinfopoli.7.2017.0228

Winseck, D. (2020). Is the International Telecommunication Union still relevant in "the internet age?" lessons from the 2012 world conference on international telecommunications (WCIT. In G. Balbi \& A. Fickers (Eds.), History of the International Telecommunication Union (ITU) (pp. 135-166). De Gruyter. https://doi.org/10.1515/9783110669701-007

Yeltsin, B., \& Zemin, J. (1997). Russian-Chinese joint declaration on a multipolar world and the establishment of a new international order (A/52/50 S/1997/384). United Nations. https://digitallibrary.un.org/record/234074/files/A_52_153_S_1997_384-EN.pdf

Zhao, Y. (2015). The BRICS formation in reshaping global communication: Possibilities and challenges. In K. Nordenstreng \& D. Thussu (Eds.), Mapping BRICS media (pp. 66-86). Routledge. https://doi.org/10.4324/9781315726212-5 